\title{
Untangling intense engagement in entrepreneurship: Role overload and obsessive passion in early-stage entrepreneurs
}

\author{
Silvia Stroe ${ }^{\mathrm{a}, *}$, Joakim Wincent ${ }^{\mathrm{b}, \mathrm{c}}$, Vinit Parida ${ }^{\mathrm{d}, \mathrm{e}}$ \\ a Politecnico di Milano, Department of Management, Economics and Industrial Engineering, Via Lambruschini 4/b, 20156 Milan, Italy \\ ${ }^{b}$ Hanken School of Economics, Department of Management and Organization, P.O. Box 479, FI-00101 Helsinki, Finland \\ ${ }^{\mathrm{c}}$ University of St. Gallen, 9000 St. Gallen, Switzerland \\ ${ }^{\mathrm{d}}$ Luleå University of Technology, Entrepreneurship and Innovation, SE-971 87 Luleå, Sweden \\ ${ }^{\mathrm{e}}$ University of Vaasa, Department of Management, Vaasa, Finland
}

\section{ABSTRACT}

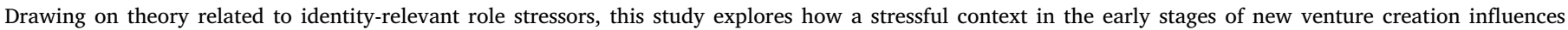

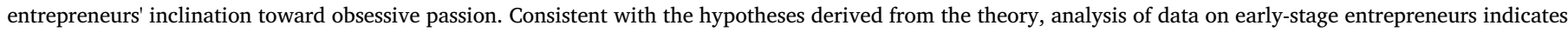

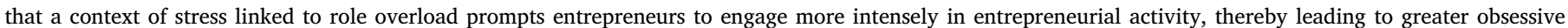

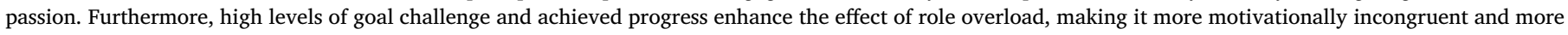
motivationally relevant for the entrepreneur. This effect increases entrepreneurs' inclination toward obsessive passion.

This research did not receive any specific grant from funding agencies in the public, commercial, or not-for-profit sectors.

\section{Introduction}

Passion has been identified as a core characteristic of entrepreneurial behavior (Bird, 1989; Locke, 2000) and "perhaps the most observed phenomenon of the entrepreneurial process" (Smilor, 1997, p. 342). Passion is considered essential for individuals to engage in an activity that is inherently uncertain and requires them to deal with resource shortages. In short, individuals need passion to persevere in the intense, risky, stressful pursuit of entrepreneurship (Timmons, 2000). Furthermore, numerous researchers report that passion influ-ences entrepreneurs' creativity, information processing, and decision making (Cardon, Wincent, Singh, \& Drnovsek, 2009; Stroe, Parida, \& Wincent, 2018), with positive effects on entrepreneurs' behavior and performance (Drnovsek, Cardon, \& Patel, 2016; Mueller, Wolfe, \& Syed, 2017).

Although the entrepreneurship literature cites passion as a central characteristic of entrepreneurs, not all forms of passion are equal. When passion takes on an obsessive quality, its effect can be problematic and even harmful for entrepreneurs. Social psychology has shown that obsessive passion can have a host of detrimental effects such as negative affect, reduced well-being, burnout, conflicts with one's personal life,

\footnotetext{
* Corresponding author.

E-mail addresses: ioanasilvia.stroe@polimi.it(S. Stroe), joakim.wincent@hanken.fi (J. Wincent), vinit.parida@ltu.se (V. Parida).
}

biased decision making, and misguided efforts to move forward with an idea or proposal despite negative feedback (Ho \& Pollack, 2014; Philippe, Vallerand, Houlfort, Lavigne, \& Donahue, 2010; Vallerand et al., 2003; Vallerand et al., 2008). The effects of obsessive passion on the venture and the entrepreneurial process, however, do not seem to be negative. Obsessive passion has been shown to lead to greater engagement in passionate activity (Vallerand et al., 2007; Vallerand, Mageau, et al., 2008) and, because of its nature as a consuming passion, may be associated with greater entrepreneurial intensity. Indeed, obsessive passion seems to be preferred by investors (Murnieks, Cardon, Sudek, White, \& Brooks, 2016) because its intensity signals behaviors that investors value in entrepreneurs.

Because the outcomes of passion depend on the type of passion and because obsessive passion can turn entrepreneurship into an extreme experience (Schindehutte, Morris, \& Allen, 2006), understanding what reinforces this phenomenon and makes a particular type of passion operative is crucial. Building on research into intrinsic versus extrinsic motivation and self-determination theory, Vallerand et al.'s (2003) dualistic model offers a theoretical basis for explaining the emergence of different qualities of passion in domains such as sports or work. Nevertheless, little is known about how different types of passion develop after they emerge and why one type of passion dominates another.

The goal of this study is to explore how identity-relevant stressors influence the type of passion that entrepreneurs develop. We present 
initial empirical evidence of why entrepreneurs' passion may become obsessive by revealing the importance of context for the type of affective engagement that entrepreneurs develop toward the entrepreneurial activity. To do so, we use the theory of identity-relevant role stressors (Kahn, Wolfe, Quinn, Snoek, \& Rosenthal, 1964; Thoits, 1991), which explains that strains which threaten to disrupt the successful enactment of a salient role identity (identity-threatening stressors) critically influence the psychological and affective functioning of individuals. Specifically, we explore the way in which a stressful context during early-stage entrepreneurship molds the nature of passion. To do so, we develop and test hypotheses regarding what determines the obsessive nature of passion among early-stage entrepreneurs. We posit that when experiencing role overload, entrepreneurs resolve this identity-relevant stressor by excessively engaging in the passionate entrepreneurial activity, which thus affects the nature of their passion. We collected empirical data using a survey in which entrepreneurs reported their perceived role overload and feelings of passion at two times. Drawing on the transactional model of stress and coping, which posits that stressrelated responses depend not only on the character of the person but also on the nature of the task and environment (Lazarus, 1993; Lazarus \& Folkman, 1984), we tested the moderating effect of goal challenge and perceived progress on the relationship between role overload and the nature of passion. By shedding light on differences between types of passion, we contribute to the literature in several ways.

First, we respond to entrepreneurship scholars' calls for research into the determinants of passion in entrepreneurship (Cardon, Foo, Shepherd, \& Wiklund, 2012; Murnieks, Mosakowski, \& Cardon, 2014). Here, we refer not only to the presence of passion but also to its nature. Our research clarifies what it is that makes passion take on an obsessive and not a harmonious quality in an entrepreneurial context. To this end, we consider the role of context and acknowledge the prominent influence of the stressor of role overload on entrepreneurs' obsessive pas-sion. The present study's foundations differ from those of previous re-search, where passion is assumed to be merely the result of a positive experience. This study thus complements the emerging body of literature presenting models that explain what determines passion (Gielnik, Spitzmuller, Schmitt, Klemann, \& Frese, 2015; Murnieks et al., 2014).

Second, we broaden the view of the relationship between role overload and obsessive passion by integrating the transactional theory of stress and coping. This helps us better understand how role overload may be experienced with different intensities depending on its motivational incongruence and relevance. We examine goal challenge and achieved progress as moderators that affect the intensity of role overload, making role overload more motivationally incongruent and motivationally relevant for the entrepreneur's self. This effect in turn increases entrepreneurs' orientation toward obsessive passion.

Third, we bridge a gap in the passion literature arising from a neglect of early-stage entrepreneurial experiences and the way they shape affective engagement in the venture. Entrepreneurial intensity varies depending on the stage of the entrepreneurial process. The early stage of the venture is a period of intense entrepreneurship. It is a time when risk-taking and proactiveness are at their peak. We address the lack of attention on this issue in two ways: first, by focusing on how circumstances in early-stage entrepreneurship influence the type of passion developed by entrepreneurs and, second, by shedding light on the intensity of the entrepreneurial process at an early stage. We test our hypotheses using a sample of early-stage entrepreneurs to investigate differences in the nature of their passion for the venture.

\section{Theoretical foundations and hypotheses}

\subsection{Harmonious versus obsessive passion}

The dualistic model of passion originated in the psychology literature. Recently, however, researchers have begun to explore its effects in organizational and entrepreneurial contexts (e.g., Forest, Mageau,
Sarrazin, \& Morin, 2011; Stroe, 2017; Thorgren \& Wincent, 2013). In the dualistic model, passion is defined as "a strong inclination toward an activity that people like, that they find important, and in which they invest time and energy" (Vallerand et al., 2003, p. 756). Besides this strong desire for an activity that people like, an additional defining characteristic of passion is that the activity that invokes the passionate response is internalized in an individual's identity (Vallerand et al., 2003). In differentiating between harmonious and obsessive passion, the dualistic model of passion focuses on how an activity is internalized in an individual's identity-that is, in a volitional or a pressured way, respectively-and whether the person engages in the entrepreneurial activity in a balanced or rigid way.

In line with this dualistic view, Vallerand et al. (2003) proposed that two distinct types of passion could develop. These types of passion are harmonious and obsessive passion. Harmonious passion refers to willed, controllable integration whereby the entrepreneurial activity is seen as important but not all consuming (Bélanger, Lafrenière, Vallerand, \& Kruglanski, 2013; Vallerand et al., 2003). Harmoniously passionate entrepreneurs can control their engagement in venture-related activity. For such entrepreneurs, this activity does not take over their lives, and it is well integrated with other life domains. In contrast, obsessive entrepreneurial passion refers to an uncontrollable urge to partake in the activity (Vallerand et al., 2003). For example, an obsessive entrepreneur continues to work weekends despite experiencing negative consequences and receiving no support from family or other individuals. Stopping would even affect his or her self-esteem. Consequently, the activity becomes difficult for an obsessively passionate entrepreneur to regulate and integrate with other life domains (Bélanger et al., 2013; Vallerand et al., 2003). Harmonious and ob-sessive passion thus differ in terms of whether the entrepreneur bal-ances the time that he or she spends on the venture activity and other life domains (harmonious) or whether the venture activity takes on an overwhelming role in the entrepreneur's life (obsessive). If passion is harmonious, the activity remains under the entrepreneur's control. If, on the other hand, passion is obsessive, the activity controls the en-trepreneur (Ho \& Pollack, 2014; Vallerand et al., 2003).

The dualistic model of passion acknowledges the important role of context in the entrepreneur's optimal functioning and therefore in the form of passion that the entrepreneur develops (Deci \& Ryan, 2000; Vallerand, 2010). While an autonomy-supportive context helps entrepreneurs maintain a balance and enjoy engaging in the activity, a pressured context prompts the entrepreneur to engage intensely in the venture activity, which begins to occupy a disproportionately large space in his or her life (Vallerand et al., 2003). Starting with these theoretical foundations and building on the theory of identity-relevant stressors and the transactional theory of stress and coping, we examine whether the interpersonal and intrapersonal context surrounding the entrepreneur determines the type of passion that develops.

\subsection{Role overload as a determinant of the nature of passion}

Individuals who have taken the leap and started a new venture are passionate and perceive that the role identity of an entrepreneur has a high value for themselves (Bird, 1989; Smilor, 1997). During the early stage of new venture development, however, specific environmental circumstances and the task characteristics of the venture might still influence the qualitative development of their passion (Vallerand, 2010; Vallerand et al., 2003).

Sociologists and psychologists acknowledge the importance of stress in the process of identity forming (Thoits, 1991). The theory on role stress and role stressors (Kahn et al., 1964) states that difficult contexts such as entrepreneurship can seriously influence an individual's affective state. Along with role conflict and role ambiguity, role overload is a critical stressor in early-stage entrepreneurship (Örtqvist \& Wincent, 2006). Early-stage entrepreneurs have heavy workloads, face personal and business risks, and have a greater need for achievement than 
individuals in other roles do (Harris, Saltstone, \& Fraboni, 1999; Rahim, 1996). Founding a venture involves numerous commitments, deadlines, time pressures, and pressured evaluations, so early-stage entrepreneurs often become overburdened (Duran-Whitney, 2004). When launching and developing new ventures, early-stage entrepreneurs face a daunting array of potential environmental stressors, notably an intense work-load, also defined as role overload (Örtqvist \& Wincent, 2006; Parasuraman, Purohit, Godshalk, \& Beutell, 1996). Role overload is a role stressor representing the degree to which people are cognitively overtaxed because of excessive time pressure, commitments, and re-sponsibilities for the available capabilities and resources (Reilly, 1982). Role overload occurs when high role demands cannot be managed within a given time period and are not accompanied by the skills and abilities to cope with such demands. It also refers to the related stress (Kahn et al., 1964; Peterson et al., 1995). Role overload implies the entrepreneur must simultaneously pursue different-sometimes com-peting-goals, forcing the entrepreneur to act ambidextrously to meet all objectives. Research has shown that role overload contributes significantly to strain, potentially leading to psychiatric symptoms (Rahim \& Psenicka, 1996), increased psychological tension (French Jr. \& Caplan, 1972), greater emotional exhaustion, and burnout (Cordes, Dougherty, \& Blum, 1997; Fogarty, Singh, Rhoads, \& Moore, 2000). Yet stressors such as role overload can also fuel individuals' energy and competitive spirit and provide the pressure needed to perform well (Filion, 1991). According to previous research, the effects of role overload on cognitive functioning mean that role overload might also have affective outcomes (Kahn et al., 1964) and therefore influence the nature of the passion developed by the entrepreneur.

Notably, certain scholars have hypothesized the opposite relation: a positive effect of obsessive passion on role overload in the case of teachers and owner-managers (Lavigne, Forest, Fernet, \& Crevier-Braud, 2014; Thorgren \& Wincent, 2013). The view that emotional experiences such as obsessive passion can have a direct causal influence on entrepreneurs' perceptions and behavior is intuitively appealing, and this view has been widely assumed by emotion researchers (e.g., Russell, 2003). There are nonetheless theoretically grounded reasons to propose the opposite. In their theory of emotions as feedback systems, Baumeister, Vohs, Nathan DeWall, and Zhang (2007) suggest that emotional experiences such as passion are often the consequence of people's perceptions and behavior rather than a direct causal antecedent thereof. According to this theory, perceptions and behavior result in outcomes (such as role tensions), and the subsequent appraisal process of the outcomes leads to emotional experiences. Therefore, entrepreneurial role stressors might affect obsessive passion. In this study, we follow this line of reasoning and hypothesize that the role overload experienced by entrepreneurs influences their obsessive passion.

In doing so, we draw on the theory of identity-relevant stressors, which suggests that the role identity as an entrepreneur gives individuals a sense of meaning and purpose and provides behavioral guidance (Thoits, 1983). Because the role expectations linked to entrepreneurship are normative, the adequacy of entrepreneurs' identity performance has implications for self-evaluation (Hoelter, 1983; Sieber, 1974). A failure to meet normative expectations in identity performance should influence one's self-concept and self-esteem. This failure is therefore expected to be an important factor in passion development. Role overload embodies an identity-relevant stressor in that it represents a potential threat to one's self-image, arising from the possible failure of meeting the role requirements of an entrepreneur. In other words, role overload creates strains that threaten to disrupt the entrepreneurs' salient role identity (Thoits, 1991). Therefore, entrepreneurs perceive role overload as stress-that is, an imbalance that must be resolved. Feeling overloaded in a role that is an important part of their identity prompts entrepreneurs to engage more intensely, both cognitively and behaviorally, in the venture in an attempt to resolve this conflict and regain control over the self-defining role. Time is a limited resource, so the increased time and energy devoted to the entrepreneurial role will reduce the time available for other roles such as family. Moreover, venture-related thoughts will be likely to occupy the entrepreneur's mind, even when he or she is engaging in other activities. Therefore, the entrepreneurial activity is more likely to occupy excessive space in the entrepreneur's life, causing conflicts with other activities (House \& Rizzo, 1972; Kahn et al., 1964). Specifically, we hypothesize that role overload will lay the foundations for the development of obsessive passion by imposing additional pressures and encouraging more intense activity engagement:

H1. Greater role overload of early-stage entrepreneurs is associated with a greater inclination toward obsessive passion.

\subsection{The moderating effects of goal challenge and achieved progress}

Not all entrepreneurs respond uniformly to role-related phenomena such as role overload (Morris \& Snyder, 1979; Van Sell, Brief, \& Schuler, 1981). The transactional theory of stress and coping (Lazarus, 1993; Lazarus \& Folkman, 1984) states that stress is not a property of the person, but arises in conjunction with a particular type of task and environment (Lazarus, 1991b). The intensity of emotional reactions to stress depends on the degree to which individuals appraise environmental demands as threatening and challenging (Lazarus \& Folkman, 1984). The individual's appraisal of the stress in the environment is based on two considerations. The first is the degree of motivational congruence or incongruence of the stressful circumstance-that is, whether the circumstance thwarts or facilitates an individual's goals (Smith \& Lazarus, 1990). The second is the motivational relevance of the circumstance (Smith \& Lazarus, 1990)—that is, the degree to which "there is a personal stake in the encounter" (Lazarus, 1993, p. 6). Motivational incongruence and relevance signal stressful situations involving challenges and threats to the individual's well-being (Lazarus, 1991a) and thus generate the potential for a highly activating, albeit negatively valenced, emotion (Lazarus, 1991b). We therefore tested whether goal challenge and achieved progress act as moderators that make entrepreneurs react more obsessively to role overload that threatens their role identity as entrepreneurs.

\subsubsection{Goal challenge}

When an entrepreneur has more challenging goals, the motivational incongruence of role overload is more arousing and overwhelming. A challenging goal leads the overloaded entrepreneur into a deeper state of maladaptive stress because the perceived discrepancy between the actual and desired conditions is greater and occupies more cognitive capacity (Bandura, 1991). The stress and distraction of task focus caused by overwhelming role demands lead to an even more intense and onesided engagement when goals seem difficult to achieve. With challenging tasks, the entrepreneur is unlikely to resolve the role overload without engaging intensely in the activity. In such a stressladen environment, the cognitive pressure and threat of failure cause the early-stage entrepreneur to feel an urgent need to engage in the venturing activity to resolve the high discrepancy. This enhances the obsessive side of passion. We thus predict the following:

H2. The positive relationship between role overload and obsessive passion of early-stage entrepreneurs is reinforced by a higher level of goal challenge.

\subsubsection{Achieved progress}

The impact of role stressors on the individual depends on the identity relevance of the roles affected by stressors (Smith \& Lazarus, 1990; Thoits, 1991). Role identities vary in terms of their salience in determining individuals' self-conceptions (Rosenberg, 1979; Stryker \& Serpe, 1982). The more salient the role identity, the more meaning, purpose, and behavioral guidance the individual derives from enacting 
the role. We thus expect a salient role identity to exert a greater influence on the entrepreneur's psychological well-being. Research has shown that roles that are enacted competently are likely to be more salient in an individual's identity hierarchy (Hoelter, 1983; Rosenberg, 1979). We therefore tested whether entrepreneurs with higher perceived progress levels in venture-related activities respond to the identity-threatening stressor of role overload more intensely than entrepreneurs with lower levels of perceived progress.

Experiencing role overload should be more identity relevant if the entrepreneur has already progressed with the venture's goals and has experienced the resulting feelings of competence (Deci \& Ryan, 2000; Vallerand et al., 2003). When threatening to disrupt an individual's salient role identity, stressors such as role overload will spur on entrepreneurs to engage longer and more intensely in the venture activity than in lower-valued role involvements, examples of which include entrepreneurs that have achieved little toward pursuing their ventures. Experiencing role overload when goal progress and competence have been experienced constitutes a higher threat for self-integrity, so thoughts about venture-related tasks might encroach on other activities and cause conflicts with other life domains. This process is expected to encourage development of an obsessive form of passion. We therefore posit the following:

H3. The positive relationship between role overload and obsessive passion of early-stage entrepreneurs is reinforced by a higher level of achieved goal progress.

\section{Method}

\subsection{Empirical setting and data collection}

This paper explores how role overload influences the way early-stage entrepreneurs adopt the entrepreneurial role identity and how the various intensities of this role stressor mold the type of passion developed by the entrepreneur. Consistent with our research aims and the finding that passion can fluctuate over short periods when entrepreneurs first start their ventures (Gielnik et al., 2015), our goal was to identify a sample of active entrepreneurs who had already started the new venture process, but who were still at an early stage. We therefore gathered the data during a start-up event for early-stage entrepreneurs in Berlin (Germany) in July and August 2014. Start-up events have been recognized as a launch pad for early-stage entrepreneurs (Fishback, Gulbranson, Litan, Mitchell, \& Porzig, 2007; Ross \& Byrd, 2011). This data gathering design excluded latent nascent entrepreneurs (Reynolds et al., 2005), who intend to engage in opportunity exploitation but have taken no specific steps toward starting a new venture. It also excluded new ventures that were already up and running. A survey was used to gather the data at two times for 45 nascent entrepreneurs. One of the authors met the entrepreneurs personally and administered the survey questionnaire. This process encouraged participants to answer the questions reflectively and thereby lowered problems related to introspection (Schweiger, Anderson, \& Locke, 1985), which are common when surveying affect and cognitions. The survey was previously piloted with three doctoral researchers, the event organizers, and two entrepreneurs, who gave feedback and advice. To ensure a high quality of responses, the questionnaire was kept short. A total of 50 entrepreneurs completed the first questionnaire before the event began. The second questionnaire was sent by email two weeks after questionnaire 1 , and 48 participants completed and returned the questionnaire. Of these 48 responses, two were incomplete and one had unacceptably low reliability, indicating that the respondent had not taken the survey seriously. After these three responses had been removed, the final sample comprised 45 entrepreneurs that had fully completed both questionnaires.

The average age in the sample was 32 , and $66 \%$ of respondents were men. The respondents were highly educated, with $69 \%$ having earned a college degree. The average number of years of work experience across the entire sample was six years. The majority had no previous entrepreneurial experience.

\subsection{Measures}

To assess entrepreneurs' orientation toward obsessive passion, we employed an established method of computing scores. This method has been used in psychology to examine subjects' relative intrinsic versus extrinsic motivation orientation (Deci \& Ryan, 2000; Schmuck, Kasser, \& Ryan, 2000; Sheldon \& Krieger, 2004) and in entrepreneurship to measure the preference for effectual or causal decision-making logic (Engel, Dimitrova, Khapova, \& Elfring, 2014; Murnieks, Haynie, Wiltbank, \& Harting, 2011). We computed a relative obsessive orientation passion score by subtracting the harmonious index from the obsessive index at $\mathrm{t} 2$. High scores thus reflect a higher relative obsessive orientation.

To measure the two types of passion, we employed Vallerand et al.'s (2003) widely accepted measure, which has been reported to have high levels of validity and reliability for a range of activities and languages. The original scale was applied to a generic activity, so we reworded the items to refer to entrepreneurial activity. Given the time constraints in this research context, we used the abridged version of the passion scale with two items for each type of passion. Whenever time constraints prevent the use of longer measures, short measures should be used, provided they have adequate psychometric properties and proven validity (Tashakkori \& Teddlie, 2010). Consistent with previous research, the psychometric properties and validity of the short versions of the passion scale have been shown to be similar to the properties and validity for the full measure (Vallerand et al., 2008; Vallerand, Mageau, et al., 2008). Both subscales used to measure within-person-surplus had acceptable internal consistency: Cronbach's $\alpha=0.79$ and 0.80 for obsessive and harmonious passion, respectively. The items were rated on a 5 -point Likert scale ( $1=$ not at all, $5=$ to a very great extent).

Role overload was measured using the established 3-item scale by Beehr, Walsh, and Taber (1976), adapted for the entrepreneurial role. The items were rated on a 5-point Likert scale $(1=$ not at all, $5=$ to $a$ very great extent). A sample item is, "I do not have any free time in my role as an entrepreneur." The measure yielded acceptable internal consistency, with a composite reliability of 0.714 (Hair Jr., Anderson, Tatham, \& Black, 1998).

Consistent with previous goal-challenge research (Locke, Latham, \& Erez, 1988), goal challenge was measured using a single 5-point Likert scale ( $1=$ not at all, $5=$ to a very great extent): "How difficult do you think it will be for you to turn your idea into a real business?" (Latham, Mitchell, \& Dossett, 1978). Although single-item measures are usually less reliable, this statement captures the very essence of goal challenge better than multi-item scales do (see Yukl \& Latham, 1978).

The level of achieved goal progress was measured using Gielnik et al.'s (2015) adaptation of van Gelderen, van de Sluis, and Jansen's (2005) 7-item scale, which assesses the perceived level of goal achievement for several aspects of the venture. The participants rated seven items on a 5-point Likert scale $(1=$ not at all, $5=$ to a very great extent). The measure had a Cronbach's $\alpha$ of 0.88 .

Respondents were asked to report their age, gender, education level, and work and entrepreneurial experience. These data were used as control variables, as in previous entrepreneurship studies (Byrnes, Miller, \& Schafer, 1999; Chen, Yao, \& Kotha, 2009; Hayward, Shepherd, \& Griffin, 2006; Kanfer \& Ackerman, 2004; Vallerand et al., 2007). We also controlled for relative obsessive passion orientation at t1. Entrepreneurs' age was measured by asking how old they were at the time that data were collected. Gender was coded as 1 for male and 2 for female. The education variable was coded as 1 for university degree and 0 for no university degree. Entrepreneurial experience and work experience were captured by the number of years of prior involvement in new ventures as an entrepreneur and number of years in employment, 
respectively. Relative obsessive passion orientation at $\mathrm{t} 1$ was computed by subtracting the harmonious index from the obsessive index at $\mathrm{t} 1$ using the short dualistic passion scale (Vallerand, Mageau, et al., 2008; Vallerand, Ntoumanis, et al., 2008).

\subsection{Common method bias considerations}

To control for possible common method biases, we followed recommendations by Podsakoff and Organ (1986) and Podsakoff, MacKenzie, Lee, and Podsakoff (2003). First, we collected data on the explanatory and dependent variables at different times. Second, during data collection, we took several steps to control for common method bias, such as assuring respondents that their responses would remain anonymous and confidential and emphasizing that there were no right or wrong answers (Podsakoff et al., 2003). Third, Harman's one-factor analysis failed to reveal a dominant first unrotated principal component (eigenvalue: 4.44, cumulative variance: $30 \%$ ), indicating that common method bias should not unduly affect the findings (Podsakoff et al., 2003). Fourth, we followed Gaskin's (2012) and Podsakoff et al.'s (2003) suggestions and analyzed our data using the unmeasured latent factor method approach. We allowed all self-reported items to load both on their theoretical constructs and on an uncorrelated method factor and compared the results of this model with our full factor measure-ment model without the latent method factor. Only 0.053 of the var-iance was accounted for by the method factor, significantly below the 0.500 cutoff value (Hair Jr. et al., 1998). In addition, the regression weights had differences of $<0.200$ when the common latent factor was added. This value shows that the variance explained by our indicators was almost the same after adding the common latent factor. These re-sults imply that common-method bias was unlikely to have influenced the present study's results, thereby allowing us to begin the hypothesis testing.

\section{Results}

Table 1 presents the descriptive statistics and sample correlations for the study variables. Overall, the correlations among the independent variables were modest. To ensure multicollinearity was not an issue, we computed variance inflation factors (VIF) for all regression models used to test the hypotheses. Most values of all first-order terms were considerably $<2$, with only two values $>2$, below the rule-of-thumb cutoff of 10 for regression models (Hair Jr. et al., 1998). The models were also robust to including or excluding variables. Therefore, multi-collinearity was not an important issue in the results.

The hypothesized relationships were tested using hierarchical regression analysis (Bagozzi, 1994; Cohen \& Cohen, 1983). Studies with small samples are common in entrepreneurial research (Short, Ketchen, Combs, \& Ireland, 2010), and using regression analysis avoids issues of model fit that can become problematic when using structural equation
Table 2

Hierarchical regression analysis: Independent and interaction effects on obsessive passion orientation.

\begin{tabular}{lllll}
\hline & Model I & Model II & Model III & Model IV \\
\hline Age & 0.01 & 0.06 & & \\
Gender & 0.06 & 0.03 & & \\
Education & 0.12 & 0.06 & & \\
Founding experience & $0.52^{*}$ & $0.43^{* * *}$ & & \\
Working experience & -0.13 & -0.15 & & \\
Relative OP orientation t1 & $0.51^{* * *}$ & $0.39^{* *}$ & & \\
Role overload & & $0.34^{*}$ & & \\
Goal challenge & & 0.01 & & \\
Perceived goal progress & & -0.06 & & \\
Overload $\times$ challenge & & & $0.33^{*}$ & \\
Overload $\times$ progress & & & & $0.36^{* * *}$ \\
$R^{2}$ & $0.43^{* * *}$ & $0.52^{* * * *}$ & $0.60^{* * * *}$ & $0.63^{* * *}$ \\
Adj. $R^{2}$ & $0.33^{* * *}$ & $0.39^{* * * *}$ & $0.48^{* * *}$ & $0.52^{* * * *}$ \\
$\Delta R^{2}$ & & $0.09^{* * *}$ & $0.08^{* * *}$ & $0.11^{* * *}$ \\
\hline
\end{tabular}

Note: The table displays standardized regression coefficients.

${ }^{*} p<0.05$.

*** $p<0.01$.

**** $p<0.001$.

modeling with small data sets (Kline, 2005). As recommended by Aiken and West (1991), the independent variables were mean-centered and standardized prior to forming the interaction terms. In each step of the hierarchical analysis, incremental $R^{2}$ and $F$ tests of statistical significance were evaluated. The regression results appear in Table 2. We first entered the control variables in the base model (Model I), followed by the independent variables in the main effects model (Model II). In the third and fourth steps, we included the interaction terms in the full models (Model III and Model IV).

As expected, role overload was found to have a statistically significant influence on obsessive passion orientation $(\beta=0.34, p<0.05)$. The data therefore support Hypothesis 1 . In addition, as expected, goal challenge and achieved progress were observed to moderate the relationship between role overload and obsessive passion orientation. In addition to observing coefficients in the expected di-rections, we observed that the interaction effect of role overload and goal challenge on obsessive passion was statistically significant $(p<0.05)$. This was also the case for the interaction effect of role overload and achieved progress on obsessive passion $(p<0.01)$. The data therefore support both Hypotheses 2 and 3.

We plotted the effect of role overload on obsessive passion orientation for high and low levels of goal challenge and perceived progress. Values of the moderators were set at 1 standard deviation (SD) above and below the mean, as suggested by Cohen and Cohen (1983). Our results illustrate a considerable difference in obsessive passion orientation. Accordingly, individuals with high levels of role overload experience much higher levels of obsessive passion if they have

Table 1

Means, standard deviations, and Pearson's correlations.

\begin{tabular}{|c|c|c|c|c|c|c|c|c|c|c|c|c|}
\hline$N=45$ & Mean & SD & VIF & 1 & 2 & 3 & 4 & 5 & 6 & 7 & 8 & 9 \\
\hline 1. Obsessive passion orientation & -1.98 & 2.06 & & & & & & & & & & \\
\hline 2. Age & 32.16 & 7.46 & 2.12 & 0.06 & & & & & & & & \\
\hline 3. Gender & - & - & 1.26 & -0.07 & -0.01 & & & & & & & \\
\hline 4. Education & - & - & 1.23 & 0.05 & 0.07 & 0.00 & & & & & & \\
\hline 5. Founding experience & 1.36 & 3.84 & 1.80 & $0.42^{* * *}$ & $0.43^{* *}$ & 0.13 & 0.02 & & & & & \\
\hline 6. Working experience & 5.56 & 6.02 & 2.86 & 0.18 & $0.69 * *$ & 0.09 & -0.06 & $0.63^{* *}$ & & & & \\
\hline 7. OP orientation $t 1$ & -2.37 & 1.97 & 1.52 & $0.44^{* * *}$ & -0.17 & $-0.35^{*}$ & -0.16 & -0.07 & -0.05 & & & \\
\hline 8. Role overload & 2.99 & 0.77 & 1.27 & $0.47^{* *}$ & -0.01 & 0.01 & 0.06 & 0.22 & 0.13 & $0.29^{* * * *}$ & & \\
\hline 9. Goal challenge & 3.31 & 0.82 & 1.21 & -0.13 & -0.06 & 0.07 & $-0.33^{*}$ & -0.01 & -0.02 & -0.20 & -0.03 & \\
\hline 10. Perceived progress & 2.96 & 0.88 & 1.22 & -0.14 & -0.14 & -0.21 & -0.14 & -0.24 & $-0.31^{*}$ & -0.01 & -0.03 & 0.24 \\
\hline
\end{tabular}

\footnotetext{
* $p<0.05$.

*** $p<0.01$.

*** $p<0.001$.
} 
challenging goals. In addition, highly overloaded entrepreneurs who have already achieved some progress develop a more obsessive passion that those who have not.

\section{Discussion}

Despite abundant anecdotal evidence of passion as a common characteristic of entrepreneurs, academic research that explains how an obsessive form of passion develops is scarce. The present study lends support to the theory that entrepreneurial passion is not simply an innate trait (Markman, Baron, \& Balkin, 2003), but rather a unique affective experience influenced by the circumstances at the beginning of the venture process (Cardon et al., 2009). This finding is important because of entrepreneurship's role as a driver of economic growth (Audretsch, Thurik, Verheul, \& Wennekers, 2002; Carree \& Thurik, 2003). If entrepreneurial passion is not simply a personality trait and if entrepreneurs can begin to understand what determines the kind of the passion that drives them, they may also be able to harness and mold that passion to ensure it leads to positive outcomes and spurs them on to achieving their goals.

This paper focuses on the intense entrepreneurial experience of early-stage entrepreneurs (Schindehutte et al., 2006) and provides evidence that role overload leads to a tendency toward obsessive passion. Drawing on theory on identity-relevant role stressors (Kahn et al., 1964; Thoits, 1991), our theoretical framework and hypotheses acknowledge how role overload fosters obsessive passion. Furthermore, with support from the transactional theory of stress and coping, we provide evidence that a high level of goal challenge and a high level of perceived progress can enhance this relationship by accentuating role overload's motivational incongruence and relevance. The findings presented herein therefore suggest that a better understanding of the obsessive side of passion requires acknowledgment of the importance of role stressors in early-stage entrepreneurship. To resolve the time pressure and multitude of commitments they face on a daily basis, entrepreneurs invest significant time, effort, and cognitive resources in their ventures. In doing so, they nurture the obsessive side of their passion. This obsessive passion becomes even more intense when entrepreneurs have set challenging goals for their venture or when they have a lot to lose from not resolving the overload because they have already achieved progress.

This paper offers a new perspective for examining passion and passion development by acknowledging the influencing role of identityrelevant stressors on the nature of passion. Scholars have identified role overload as a prominent characteristic of entrepreneurs because of the many demands of their role and the scarcity of available resources (Parasuraman et al., 1996; Rahim, 1996). The nature of the passion that is developed by early-stage entrepreneurs has also been discussed as obsessive (Murnieks et al., 2016; Smilor, 1997). Readers may agree that these discussions support the face validity of our framework. Indeed, entrepreneurs might develop an obsessive form of passion because of the intensity of the experiences related to the early-stage venture itself. We encourage scholars to investigate further into the new theoretical mechanism we use to explain how role overload might activate and develop the obsessive side of passion.

This study looked beyond the direct influence of role overload, considering its interaction with goal challenge and achieved progress, which the literature on passion had not previously discussed. We found that a high level of goal challenge coupled with role overload intensifies obsessive passion. Interestingly, this finding contradicts the argument that setting challenging goals might lead to the experience of absorptive states such as flow (Csikszentmihalyi, 1996). We call for further studies to go beyond the self-determination mechanisms that other studies have examined in connection with passion development (Bonneville-Roussy, Vallerand, \& Bouffard, 2013; Lalande et al., 2017). This paper offers an alternative by examining identity-relevant stressors. However, further research is needed for us to better understand the antecedents of passion.

\section{Limitations}

This study has several limitations. First, this study was used to test how role stressors are associated with different types of passion. Consequently, only role overload and its interactions were studied as independent variables. We nevertheless acknowledge that many exogenous variables rooted in other theories (e.g., personality traits) may contribute to developing different types of passion. Further research is needed to rule out alternative explanations. The data for the present study were collected at a start-up event, a setting that gave us access to a group of early-stage entrepreneurs. Our results cannot be generalized to all stages of entrepreneurship, so readers should interpret them with caution. Moreover, given that our sample consisted only of entrepreneurs based in Germany, our results cannot be generalized across cultures. Indeed, passion might be viewed and experienced differently in different cultures. Largely because of the difficulty in gathering data on early-stage entrepreneurs, the sample was small. Although the sample was large enough for statistical inference, the research setting may impose some limitations on the generalizability of our findings, which would be vastly improved with larger samples, as noted by McMullen and Shepherd (2006). Therefore, we advocate further re-search to replicate our baseline findings in other settings while searching for additional mechanisms to those examined in this study.

The nature of the data calls for prudence when interpreting our findings, despite strong support from our theory. Although we lowered the risk of reverse causality by using a time lag between the measurement of the independent variable (i.e., role overload) and the dependent variable (i.e., obsessive passion), we cannot rule out reverse causality. For instance, because emotions and stressors are closely intertwined (Folkman, 2008), the relationship between obsessive passion and role overload might well be intricate. In fact, Lavigne et al. (2014) and Thorgren and Wincent (2013) argue that obsessive passion influences role overload, highlighting the possibility of a circular relationship. We therefore encourage scholars to investigate the relationship between obsessive passion and role overload more thoroughly to understand how this relationship develops over time.

In this paper, we offer a snapshot of how the nature of passion develops. To gain a better grasp of this phenomenon, however, future research should track entrepreneurs' passion over a longer period with repeated measurements. Such a study would yield further insight into this issue. For example, it would explain whether passion eventually settles into a harmonious or obsessive state after the critical initial venture phase or whether a particular type of passion re-emerges and intensifies depending on the circumstances at a given time. Future studies could adopt different perspectives on the emotions, motivations, and behaviors present at the beginning of the entrepreneurial process. By doing so, we could gain a better understanding of what entrepreneurial intensity during early-stage entrepreneurship really means for entrepreneurs, the people around them, and the ventures themselves.

\section{Conclusion}

Despite its potentially negative effect on entrepreneurs' well-being, obsessive passion may form part of the affective-motivational foundation that helps entrepreneurs persevere even when facing challenges. Entrepreneurs should be aware that obsession might be an integral part of their passion and a potentially necessary response to the stress of entrepreneurial endeavors. Indeed, an obsessive passion may help maintain goal-related behavior over time and facilitate planned responses designed to assist in meeting objectives. Vilifying or trying to eradicate obsessive passion may be neither desirable nor possible without also forgoing its benefits. Similarly, entrepreneurs should understand and acknowledge all aspects of their passionate feelings. By 
doing so, they will be better prepared to regulate the negative effects of obsessive passion on their well-being while reaping its benefits as a source of motivation and resilience.

\section{References}

Aiken, L. S., \& West, S. G. (1991). Multiple regression: Testing and interpreting interactions. Newbury Park, CA: Sage.

Audretsch, D. B., Thurik, R., Verheul, I., \& Wennekers, S. (2002). Understanding entrepreneurship across countries and over time. In D. B. Audretsch, R. Thurik, I. Verheul, \& S. Wennekers (Eds.). Entrepreneurship: Determinants and policy in a European-U.S. comparison (pp. 1-10). Dordrecht: Kluwer Academic Publishers.

Bagozzi, R. P. (1994). Measurement in marketing research: Basic principles of questionnaire design. Principles of marketing research. Vol. 1. Principles of marketing research (pp. 1-49).

Bandura, A. (1991). Social cognitive theory of self-regulation. Organizational Behavior and Human Decision Processes, 50(2), 248-287.

Baumeister, R. F., Vohs, K. D., Nathan DeWall, C., \& Zhang, L. (2007). How emotion shapes behavior: Feedback, anticipation, and reflection, rather than direct causation.

Personality and Social Psychology Review, 11(2), 167-203.

Beehr, T. A., Walsh, J., \& Taber, T. (1976). Relationship of stress to individually and organizationally valued states: Higher order needs as a moderator. Journal of Applied Psychology, 61, 41-47.

Bélanger, J. J., Lafrenière, M. A. K., Vallerand, R. J., \& Kruglanski, A. W. (2013). When passion makes the heart grow colder: The role of passion in alternative goal suppression. Journal of Personality and Social Psychology, 104(1), 126-147.

Bird, B. J. (1989). Entrepreneurial behavior. Glenview, IL: Scott Foresman.

Bonneville-Roussy, A., Vallerand, R. J., \& Bouffard, T. (2013). The roles of autonomy support and harmonious and obsessive passions in educational persistence. Learning and Individual Differences, 24, 22-31.

Byrnes, J. P., Miller, D. C., \& Schafer, W. D. (1999). Gender differences in risk taking: A meta-analysis. Psychological Bulletin, 125(3), 367.

Cardon, M. S., Foo, M. D., Shepherd, D., \& Wiklund, J. (2012). Exploring the heart: Entrepreneurial emotion is a hot topic. Entrepreneurship Theory and Practice, 36(1), $1-10$.

Cardon, M. S., Wincent, J., Singh, J., \& Drnovsek, M. (2009). The nature and experience of entrepreneurial passion. Academy of Management Review, 34(3), 511-532.

Carree, M. A., \& Thurik, A. R. (2003). The impact of entrepreneurship on economic growth. In Z. J. Acs, \& D. B. Audretsch (Eds.). Handbook of entrepreneurship research

(pp. 437-471). Boston, MA: Kluwer Academic Publishers.

Chen, X. P., Yao, X., \& Kotha, S. (2009). Entrepreneur passion and preparedness in business plan presentations: A persuasion analysis of venture capitalists' funding decisions. Academy of Management Journal, 52(1), 199-214.

Cohen, J., \& Cohen, P. (1983). Applied multiple regression/correlation analysis for the behavioral sciences. Hillsdale, NJ: Erlbaum.

Cordes, C. L., Dougherty, T. W., \& Blum, M. (1997). Patterns of burnout among managers and professionals: A comparison of models. Journal of Organizational Behavior, 18,

685-701.

Csikszentmihalyi, M. (1996). Flow and the psychology of discovery and invention. New York: Harper Collins.

Deci, E. L., \& Ryan, R. M. (2000). The "what" and "why" of goal pursuits: Human needs and the self-determination of behavior. Psychological Inquiry, 11(4), 227-268. Drnovsek, M., Cardon, M. S., \& Patel, P. C. (2016). Direct and indirect effects of passion on growing technology ventures. Strategic Entrepreneurship Journal, 10(2), 194-213.

Duran-Whitney, M. (2004). Understanding occupational stress and mental health in aspiring small business owners (Unpublished DPsy thesis)Alameda, CA: California School of

Professional Psychology.

Engel, Y., Dimitrova, N. G., Khapova, S. N., \& Elfring, T. (2014). Uncertain but able: Entrepreneurial self-efficacy and novices' use of expert decision-logic under uncertainty. Journal of Business Venturing Insights, 1, 12-17.

Filion, L. J. (1991). Vision and relations: Elements for an entrepreneurial metamodel. International Small Business Journal, 9, 26-40.

Fishback, B., Gulbranson, C., Litan, R., Mitchell, L., \& Porzig, M. (2007). Finding business "idols": A new model to accelerate start-ups. The Ewing Marion Kauffman foundation

report. Vol. 4.

Fogarty, T. J., Singh, J., Rhoads, G. K., \& Moore, R. K. (2000). Antecedents and consequences of burnout in accounting: Beyond the role stress model. Behavioral Research in Accounting, 12, 31-67.

Folkman, S. (2008). The case for positive emotions in the stress process. Anxiety, Stress, and Coping, 21, 3-14.

Forest, J., Mageau, G. A., Sarrazin, C., \& Morin, E. M. (2011). Work is my passion: The different affective, behavioural, and cognitive consequences of harmonious and obsessive passion toward work. Canadian Journal of Administrative Sciences, 28(1), 2740.

French, J. R. P., Jr., \& Caplan, R. D. (1972). Organizational stress and individual strain. In A. J. Marrow (Ed.). The failure of success (pp. 30-66). New York: AMACOM.

Gaskin, J. (2012, June 6). Common method bias using common latent factor [Video file] (Retrieved from) https://www.youtube.com/watch?v =Y7Le5Vb7 jg.

Gielnik, M. M., Spitzmuller, M., Schmitt, A., Klemann, D. K., \& Frese, M. (2015). I put in effort, therefore I am passionate: Investigating the path from effort to passion in entrepreneurship. Academy of Management Journal, 58(4), 1012-1031.

Hair, J. F., Jr., Anderson, R. E., Tatham, R. L., \& Black, W. C. (1998). Multivariate data analysis. Upper Saddle River, NJ: Prentice.

Harris, J. A., Saltstone, R., \& Fraboni, M. (1999). An evaluation of the job stress questionnaire with a sample of entrepreneurs. Journal of Business and Psychology, 13(3), 447-455.

Hayward, M. L., Shepherd, D. A., \& Griffin, D. (2006). A hubris theory of entrepreneurship. Management Science, 52(2), 160-172.

Ho, V. T., \& Pollack, J. M. (2014). Passion isn't always a good thing: Examining entrepreneurs' network centrality and financial performance with a dualistic model of passion. Journal of Management Studies, 51(3), 433-459.

Hoelter, J. W. (1983). The effects of role evaluation and commitment on identity salience. Social Psychology Quarterly, 46, 140-147.

House, R. J., \& Rizzo, J. R. (1972). Role conflict and ambiguity as critical variables in a model of organizational behavior. Organizational Behavior and Human Performance,

7(3), 467-505.

Kahn, R. L., Wolfe, D. M., Quinn, R. P., Snoek, J. D., \& Rosenthal, R. A. (1964). Organizational stress. New York: Wiley.

Kanfer, R., \& Ackerman, P. L. (2004). Aging, adult development, and work motivation. Academy of Management Review, 29(3), 440-458.

Kline, T. J. (2005). Psychological testing: A practical approach to design and evaluation. Thousand Oaks, CA: Sage Publications.

Lalande, D., Vallerand, R. J., Lafrenière, M. A. K., Verner-Filion, J., Laurent, F. A., Forest, J., \& Paquet, Y. (2017). Obsessive passion: A compensatory response to unsatisfied needs. Journal of Personality, 85(2), 163-178.

Latham, G. P., Mitchell, T. R., \& Dossett, D. L. (1978). Importance of participative goal setting and anticipated rewards on goal difficulty and job performance. Journal of Applied Psychology, 63(2), 163-171.

Lavigne, G. L., Forest, J., Fernet, C., \& Crevier-Braud, L. (2014). Passion at work and workers' evaluations of job demands and resources: A longitudinal study. Journal of Applied Social Psychology, 44(4), 255-265.

Lazarus, R. S. (1991a). Progress on a cognitive-motivational-relational theory of emotion. American Psychologist, 46(8), 819-834.

Lazarus, R. S. (1991b). Emotion and adaptation. New York: Oxford University Press.

Lazarus, R. S. (1993). Coping theory and research: Past, present, and future. Psychosomatic Medicine, 55(3), 234-247.

Lazarus, R. S., \& Folkman, S. (1984). Stress, appraisal, and coping. New York: Springer publishing company.

Locke, E. A. (2000). The prime movers: Traits of the great wealth creators. New York: AMACOM

Locke, E. A., Latham, G. P., \& Erez, M. (1988). The determinants of goal commitment Academy of Management Review, 13(1), 23-39.

Markman, G. D., Baron, R. A., \& Balkin, D. B. (2003). The role of regretful thinking, perseverance, and self-efficacy in venture formation. Advances in entrepreneurship, firm emergence, and growth. Vol. 6. Advances in entrepreneurship, firm emergence, and growth (pp. 73-104).

McMullen, J. S., \& Shepherd, D. A. (2006). Entrepreneurial action and the role of uncertainty in the theory of the entrepreneur. The Academy of Management Review, 31(1), 132-152.

Morris, J. H., \& Snyder, R. A. (1979). A second look at need for achievement and need for autonomy as moderators of role perception-outcome relationships. Journal of Applied Psychology, 64(2), 173-178.

Mueller, B. A., Wolfe, M. T., \& Syed, I. (2017). Passion and grit: An exploration of the pathways leading to venture success. Journal of Business Venturing, 32(3), 260-279.

Murnieks, C. Y., Cardon, M. S., Sudek, R., White, T. D., \& Brooks, W. T. (2016). Drawn to the fire: The role of passion, tenacity and inspirational leadership in angel investing.

Journal of Business Venturing, 31(4), 468-484.

Murnieks, C. Y., Haynie, J. M., Wiltbank, R. E., \& Harting, T. (2011). 'I like how you think': Similarity as an interaction bias in the investor-entrepreneur dyad. Journal of Management Studies, 48(7), 1533-1561.

Murnieks, C. Y., Mosakowski, E., \& Cardon, M. S. (2014). Pathways of passion identity centrality, passion, and behavior among entrepreneurs. Journal of Management, 40(6),

1583-1606.

Örtqvist, D., \& Wincent, J. (2006). Prominent consequences of role stress: A meta-analytic review. International Journal of Stress Management, 13(4), 399.

Parasuraman, S., Purohit, Y. S., Godshalk, V. M., \& Beutell, N. J. (1996). Work and family variables, entrepreneurial career success, and psychological well-being. Journal of

Vocational Behavior, 48(3), 275-300.

Peterson, M. F., Smith, P. B., Akande, A., Ayestaran, S., Bochner, S., Callan, V., \& Hofmann, K. (1995). Role conflict, ambiguity, and overload: A 21-nation study. Academy of Management Journal, 38(2), 429-452.

Philippe, F. L., Vallerand, R. J., Houlfort, N., Lavigne, G., \& Donahue, E. G. (2010). Passion for an activity and quality of interpersonal relationships: The mediating role

of emotions. Journal of Personality and Social Psychology, 98, 917-932.

Podsakoff, P. M., MacKenzie, S. B., Lee, J.-Y., \& Podsakoff, N. P. (2003). Common method biases in behavioral research: A critical review of the literature and recommended remedies. The Journal of Applied Psychology, 88(5), 879-903.

Podsakoff, P. M., \& Organ, D. W. (1986). Self-reports in organizational research: Problems and prospects. Journal of Management, 12(4), 531-544.

Rahim, A. (1996). Stress, strain, and their moderators: An empirical comparison of entrepreneurs and managers. Journal of Small Business Management, 34(1), 46.

Rahim, M. A., \& Psenicka, C. (1996). A structural equations model of stress, locus of control, social support, psychiatric symptoms, and propensity to leave a job. Journal of Social Psychology, 136, 69-84.

Reilly, M. D. (1982). Working wives and convenience consumption. Journal of Consumer Research, 8, 407-418.

Reynolds, P. D., Bosma, N., Autio, E., Hunt, S., De Bono, N., Servais, I., ... Chin, N. (2005) Global entrepreneurship monitor. Data collection design and implementation 19982003. Small Business Economics, 24, 205-231.

Rosenberg, M. (1979). Conceiving the self. New York: Basic Books. 
Ross, L. W., \& Byrd, K. (2011). Business plan competitions: Start-up 'idols' and their twenty-first century launch pads. Journal of Higher Education Theory and Practice,

11(4), 53-64.

Russell, J. A. (2003). Core affect and the psychological construction of emotion. Psychological Review, 110(1), 145.

Schindehutte, M., Morris, M., \& Allen, J. (2006). Beyond achievement: Entrepreneurship as extreme experience. Small Business Economics, 27(4-5), 349-368. Schmuck, P., Kasser, T., \& Ryan, R. M. (2000). Intrinsic and extrinsic goals: Their structure and relationship to well-being in German and US college students. Social Indicators Research, 50(2), 225-241.

Schweiger, D. M., Anderson, C. R., \& Locke, E. A. (1985). Complex decision making: A longitudinal study of process and performance. Organizational Behavior and Human Decision Processes, 36(2), 245-272.

Sheldon, K. M., \& Krieger, L. S. (2004). Does legal education have undermining effects on law students? Evaluating changes in motivation, values, and well-being. Behavioral Sciences \& the Law, 22(2), 261-286.

Short, J. C., Ketchen, D. J., Combs, J. G., \& Ireland, R. D. (2010). Research methods in entrepreneurship opportunities and challenges. Organizational Research Methods, 13(1), 6-15.

Sieber, S. (1974). Toward a theory of role strain. American Sociological Review, 39, 567-578.

Smilor, R. W. (1997). Entrepreneurship: Reflections on a subversive activity. Journal of Business Venturing, 12(5), 341-346.

Smith, C. A., \& Lazarus, R. S. (1990). Emotion and adaptation. In L. A. Pervin (Ed.).

Handbook of personality: Theory and research (pp. 609-637). New York: Guilford. Stroe, I. S. (2017). The duality of passion in entrepreneurship. ((Doctoral dissertation). Retrieved from Helda Helsinki at Hanken School of Economics. (Accession No. 123456789/167979))

Stroe, S., Parida, V., \& Wincent, J. (2018). Effectuation or causation: An fsQCA analysis of entrepreneurial passion, risk perception, and self-efficacy. Journal of Business Research. http://dx.doi.org/10.1016/j.jbusres.2018.01.035 (in press)

Stryker, S., \& Serpe, R. T. (1982). Commitment, identity salience, and role behavior: Theory and research example. In W. Ickes, \& E. S. Knowles (Eds.). Personality, roles, and social behavior (pp. 199-218). New York: Springer.

Tashakkori, A., \& Teddlie, C. (2010). Sage handbook of mixed methods in social behavioral research. Thousand Oaks, CA: Sage.

Thoits, P. A. (1983). Multiple identities and psychological well-being: A reformulation and test of the social isolation hypothesis. American Sociological Review, 48(2), 74-187.

Thoits, P. A. (1991). On merging identity theory and stress research. Social Psychology Quarterly, 54, 101-102.

Thorgren, S., \& Wincent, J. (2013). Passion and role opportunity search: Interfering effects of conflicts and overloads. International Journal of Stress Management, 20(1), 20.

Timmons, J. A. (2000). New venture creation: Entrepreneurship 2000 (5th ed.). Homewood, IL: Irwin.
Vallerand, R. J. (2010). Deci and Ryan's self-determination theory: A view from the hierarchical model of intrinsic and extrinsic motivation. Psychological Inquiry, 11(4), 312-318.

Vallerand, R. J., Blanchard, C., Mageau, G. A., Koestner, R., Ratelle, C., Leonard, M., ... Marsolais, J. (2003). Les passions de l'ame: On obsessive and harmonious passion. Journal of Personality and Social Psychology, 85, 756-767.

Vallerand, R. J., Mageau, G. A., Elliot, A. J., Dumais, A., Demers, M. A., \& Rousseau, F. (2008). Passion and performance attainment in sport. Psychology of Sport and Exercise, 9(3), 373-392

Vallerand, R. J., Ntoumanis, N., Philippe, F. L., Lavigne, G. L., Carbonneau, N., Bonneville, A., ... Maliha, G. (2008). On passion and sports fans: A look at football. Journal of Sports Sciences, 26(12), 1279-1293.

Vallerand, R. J., Salvy, S. J., Mageau, G., Elliot, A. J., Denis, P. L., Grouzet, F. M. E., \& Blanchard, C. (2007). On the role of passion in performance. Journal of Personality, 75(3), 505-533.

Van Gelderen, M., van de Sluis, L., \& Jansen, P. (2005). Learning opportunities and learning behaviours of small business starters: Relations with goal achievement, skill development and satisfaction. Small Business Economics, 25(1), 97-108.

Van Sell, M., Brief, A. P., \& Schuler, R. S. (1981). Role conflict and role ambiguity: Integration of the literature and directions for future research. Human Relations, Studies Towards the Integration of the Social Sciences, 34(1), 43-71.

Yukl, G. A., \& Latham, G. P. (1978). Interrelationships among employee participation, individual differences, goal difficulty, goal acceptance, goal instrumentality, and performance. Personnel Psychology, 31(2), 305-323.

Silvia Stroe is Postdoctoral Researcher at Politecnico di Milano. Her resarch interested cover entrepreneurship, passion, new venture creation, and decision-making process. She has published in several journals, such as Journal of Business Research and conference proceedings, such as Academy of Management Proceedings.

Joakim Wincent is a professor of entrepreneurship at Hanken School of Economics and Luleå University of Technology, Sweden. His current research interests cover interorganizational exchanges, network management, managing R\&D, and organizing new venturing. He has published in several distinguished international journals, including Academy of Management Review, Organizational Research Methods, Strategic Organization, Journal of Business Venturing, and others.

Vinit Parida is a professor at entrepreneurship and innovation at Luleå University of Technology, Sweden, and a visiting professor at the University of Vaasa, Finland. His research interests include servitization, business models, open innovation, en trepreneurship and organizational capabilities. He has published several distinguished international journals, including articles in Strategic Management Journal, Journal of Management Studies, Long Range Planning, Industrial Marketing Management, Production and Operations Management, Journal of Cleaner Production, and others. 